\title{
International Legal Regulation of Copyright and Related Rights Protection in the Digital Environment
}

\author{
OLEH HUBANOV ${ }^{1}$, TAMARA HUBANOVA ${ }^{2}$, HANNA KOTLIAREVSKA ${ }^{3}$, MYKHAILO VIKHLIAIEV ${ }^{4}$, \\ VALERII DONENKO ${ }^{5}$, YULIIA LEPEKH ${ }^{6}$ \\ ${ }^{1}$ Development Strategy Implementation Department of TARAS SHEVCHENKO NATIONAL UNIVERSITY, Service \\ and Medical Law department of LAW SCHOOL OF TARAS SHEVCHENKO NATIONAL UNIVERSITY, UKRAINE, \\ E-mail: lana.bond@ukr.net ORCID: http://orcid.org/0000-0002-4816-4579 \\ ${ }^{2}$ Private Higher Educational Institution "Financial-Legal College", UKRAINE, E-mail: gubanovatamara@ukr.net \\ ${ }^{3}$ Department of Theory of Power and Law and Constitutional Law (Private Joint-Stock Company "Higher \\ educational institution "Interregional Academy of Personnel Management"), E-mail: ganna@umw.com.ua \\ ${ }^{4}$ Deputy Director of the Publishing House "Helvetica", Zaporizhzhia, E-mail: vikhliaievm@gmail.com \\ ${ }^{5}$ Department of Administrative and Customs Law, UNIVERSITY OF CUSTOMS AND FINANCE, UKRAINE, \\ E-mail: don1964dnipro@ukr.net \\ ${ }^{6}$ Department of Law, INTERREGIONAL ACADEMY OF PERSONNEL MANAGEMENT, UKRAINE,
}

E-mail: kplimaup@ukr.net

\begin{abstract}
The purpose of this article is to identify changes in the nature of the challenges and analyze key trends in international law regulation of copyright and related rights protection in the digital environment. It is established that the digital environment forms the newest type of legal relations, which requires modification of copyright legislation. International experience on the latest trends in copyright and related rights protection in the digital environment has discussed. It has established that the key trend of modification international legal regulation of copyright and related rights in the digital environment there are stricter measures to restrict online sales of pirated books, audiovisual products and electronic publications. Particular attention has paid to combating copyright infringement on social networking platforms, as well as in the field of online education, training, ecommerce. It has proved that to improve the mechanism of combating crime in the field of intellectual property it is necessary to modernize the national intellectual property system: improving the regulatory framework, improving the institutional framework and infrastructure, as well as conducting comprehensive educational work with users of this system.
\end{abstract}

Keywords: The intellectual property; The international law; A copyright; A related rights; The digital environment.

JEL classification: K33, 034, Z10

Received: April 09, 2021

Accepted: June 12, 2021 


\title{
Regulación Jurídica Internacional de la Protección de los Derechos de Autor y Derechos Afines en el Entorno Digital
}

\author{
OLEH HUBANOV ${ }^{1}$, TAMARA HUBANOVA ${ }^{2}$, HANNA KOTLIAREVSKA ${ }^{3}$, MYKHAILO VIKHLIAIEV ${ }^{4}$, \\ VALERII DONENKO ${ }^{5}$, YULIIA LEPEKH ${ }^{6}$ \\ ${ }^{1}$ Development Strategy Implementation Department of TARAS SHEVCHENKO NATIONAL UNIVERSITY, Service \\ and Medical Law department of LAW SCHOOL OF TARAS SHEVCHENKO NATIONAL UNIVERSITY, UKRAINE, \\ E-mail: lana.bond@ukr.net ORCID: http://orcid.org/0000-0002-4816-4579 \\ 2Private Higher Educational Institution "Financial-Legal College", UKRAINE, E-mail: gubanovatamara@ukr.net \\ ${ }^{3}$ Department of Theory of Power and Law and Constitutional Law (Private Joint-Stock Company "Higher \\ educational institution "Interregional Academy of Personnel Management"), E-mail: ganna@umw.com.ua \\ ${ }^{4}$ Deputy Director of the Publishing House "Helvetica”, Zaporizhzhia, E-mail: vikhliaievm@gmail.com \\ ${ }^{5}$ Department of Administrative and Customs Law, UNIVERSITY OF CUSTOMS AND FINANCE, UKRAINE, \\ E-mail: don1964dnipro@ukr.net \\ ${ }^{6}$ Department of Law, INTERREGIONAL ACADEMY OF PERSONNEL MANAGEMENT, UKRAINE, \\ E-mail: kplimaup@ukr.net
}

\begin{abstract}
RESUMEN
El propósito de este artículo es identificar los cambios en la naturaleza de los desafíos y analizar las tendencias clave en la regulación del derecho internacional de los derechos de autor y la protección de los derechos conexos en el entorno digital. Se establece que el entorno digital constituye el tipo más nuevo de relaciones jurídicas, que requiere la modificación de la legislación sobre derechos de autor. Se ha discutido la experiencia internacional sobre las últimas tendencias en la protección de los derechos de autor y derechos conexos en el entorno digital. Se ha establecido que la tendencia clave de la modificación de la regulación legal internacional de los derechos de autor y derechos conexos en el entorno digital son las medidas más estrictas para restringir las ventas en línea de libros piratas, productos audiovisuales y publicaciones electrónicas. Se ha prestado especial atención a la lucha contra la infracción de los derechos de autor en las plataformas de redes sociales, así como en el ámbito de la educación en línea, la formación y el comercio electrónico. Se ha demostrado que para mejorar el mecanismo de lucha contra la delincuencia en el ámbito de la propiedad intelectual es necesario modernizar el sistema nacional de propiedad intelectual: mejorar el marco normativo, mejorar el marco institucional y la infraestructura, así como llevar a cabo una amplia labor educativa con los usuarios de este sistema.
\end{abstract}

Palabras claves: La propiedad intelectual; El derecho internacional; Los derechos de autor; Los derechos conexos; El entorno digital.

Calsificación JEL: K33, O34, Z10

Recibido: 09 de abril de 2021

Aceptado: 12 de junio de 2021 


\section{Introduction}

\section{Relevance of the topic and problem statement}

The formation of the information society has led to the dematerialization of copyright and related rights protection. In the digital environment, certain social relations function. Entities operating in the digital environment acquire a certain legal status of individual participants in such legal relations. This is due to modifications to copyright law. The actualization of digitalization has inevitably led to a paradigm shift, which is becoming the latest challenge to the legal framework of copyright, which was previously based on tangible assets. At the same time, the dematerialization of copyrighted materials has made them more accessible (Bakulina, et al., 2019). Copyright, as a sphere of intellectual property, is a set of norms of civil and information law that regulate the relationship of recognition of authorship and protection of works of science, literature and art. Intellectual property has associated with the creativity of the economy, the latest technologies, innovations (Bondarenko, et al., 2021). The importance of protection of intellectual property from crime is especially growing in connection with the development of the world market of high technologies (Moser, 2005; Babenko, 2020). Due to the development of modern information and telecommunication technologies, new types of public relations have emerged, special physical properties of objects of exclusive rights on the Internet were manifested. The modern information technologies, the Internet resources, the digital technologies make it much easier to make unauthorized copies of copyrighted works with the help of technologically advanced equipment. With the growing popularity of streaming services Over-the-top (OTT) and services Internet Protocol Television (IPTV) is also growing with the ease with which users can illegally access, share restricted content and ignore copyright laws. Digital Rights Management (DRM) refers to software and hardware that defines, protects, and manages rules for accessing and using digital content (text, audio, video, etc.) (Bogna, 2018). Relevant components of DRM systems are technological protection measures (Trusted Platform Module, TPM) and Remote Method Invocation (RMI) information, which are also the subject of international copyright treaties (Cohen, 1998). TPMs seek to provide an effective safeguard through which content owners can control the use of their topic and access to it by third parties (Coyle, 2004).

The most widely used TPMs are encryption, digital watermarks, copy control, fingerprint control, access control, authentication key management, and other restrictions that set conditions for users of digital objects. RMI is information that identifies copyrighted or related content, the rights holders of such content, and the associated terms of use. World Intellectual Property Organization (WIPO) agreements protect all of the following RMIs: an information about works, a phonograms, and a performances, and the identification of authors, the phonogram producers, the performers, or other rights holders (Holovatyi, 2014; Cortese, 2016).

Because every fourth Internet user uses Virtual Private Network (VPN), 50\% of them recognize their main motivation for this - the ability to access content cheaper / more convenient. The digital rights holders face a direct threat to their ability to protect and monetize their content. Appropriation of property rights threatens the interests of owners.

The world's only electronic information space, the existence of which has become a natural consequence of the development of Internet technologies, requires a comprehensive approach to developing the latest model of copyright for objects hosted on the Internet (Vila, et al., 2019). Recent realities call for the legislation, the science, and the international community to rethink, regulate, and protectcopyright and related rights in the digital environment (Bondarenko, et al., 2021).

The purpose of this article is to identify changes in the nature of the challenges and to analyze key trends in international lawregulation of copyright and related rights protection in the digital environment.

For example, the experience of some selected jurisdictions, such as the United States, the European Union, China - to identify the latest trends in copyright and related rights in the digital environment. This study aims to identify gaps in Ukrainian legislation and suggest possible modifications to existing copyright and related rights legislation in line with key trends and challenges. 


\section{Literary review}

The copyright allows authors of a literary, an artistic and a scientific works to derive social benefits from the results of their creative work (Hilty, 2018; Podgorna, et al., 2020). The copyright licensing allows the manufacturer to commercialize the final work through various windows of the operation (Romanenko \& Chaplay, 2016).

According to the definition of WIPO, intellectual property refers to legal rights that are the result of intellectual activity in industry, science, literature and the arts (WIPO, 2004).

There are two main components of intellectual property:

- industrial property;

- copyright.

The industrial property includes: a patents for inventions, an industrial designs, a trademarks, etc. Copyright - property and personal non-property rights that belong to persons who have created works of science, literature and art such as books, music, paintings and sculptures, films and technological works (computer programs, electronic databases) (WIPO, 2016) .

Copyright protects the original expression of ideas, from the moment the work has created, without any prior registration or officiality.

Copyright applies to copyright and related rights.

Copyright protects two types of rights: economic and moral.

The economic rights include: the right to authorize (or prohibit) the reproduction, the public notice, the distribution, the broadcast, the public performance, the translation or the adaptation of an original work. Such rights may be transferred to a third party in exchange for payment.

The moral rights have not transferred, including the right to attribute (authorship), the right to inviolability, which may harm the work or reputation (Article 6).

For most countries, the duration of copyright is set at 50-70 years after the author's death, after which the works become public domain.

At the international level, copyright was regulated for the first time by the terms of the Berne Convention for the Protection of Literary and Artistic Works, which became a multilateral copyright convention (Berne Convention).

The Berne Convention has based on the following principles:

- The principle of the "national treatment", ie works originating in one of the Contracting States (according to the nationality or place of residence of the author or the place of first publication of the work), shall enjoy the same protection in the other Contracting States.

- The principle of the "automatic protection", ie protection has not formalized by any conditions.

- The principle of the "independence of protection", ie protection, does not depend on the existence of protection in the country of origin of the work.

The economic rights granted to the authors of a work have recognized as exclusive authorization rights, subject to certain permitted reservations, restrictions or exceptions:

- the right to translation;

- the right to adapt and arrange the work;

- the right to perform in public dramatic, dramatic-musical and musical works;

- the right of public recitation of literary works;

- the right to inform the public about the performance of such works;

- the right to broadcast;

- the right to make reproductions in any way or in any form;

- the right to use the work as a basis for an audiovisual work, to reproduce, distribute, perform in public or communicate to the public this audiovisual work. 
The Berne Convention provides for the "moral rights".

The Berne Convention has been revised several times to take into account new technological developments. The last revision took place on February 11, 2020, and 178 states were parties to the Berne Convention.

Later, in 1994, the World Trade Organization (WTO) Agreement on Trade-Related Aspects of Intellectual Property Rights (TRIPS) and the 1996 Copyright Treaty (WIPO) were adopted, which legally strengthened the Berne Convention at the international level.

The TRIPS agreement shifted copyright to world trade, which greatly extended copyright principles to even more countries. The TRIPS Agreement provides for effective copyright enforcement measures, as well as multilateral dispute settlement and transitional mechanisms.

The Treaty on the Regulation of Copyright in New Information Technologies, which is a development of the Berne Convention as a special WCT agreement, concerns the protection of works and the rights of their authors in the digital environment, gives them three new exclusive rights:

- The right to allow or prohibit the distribution to the public of original works or their copies by sale or otherwise (right of distribution);

- The right to allow or prohibit the commercial rental of cinematographic works or works embodied in phonograms (rental right);

- The right to allow or prohibit the public communication of their original works or copies thereof by wire or wireless communication, including the provision of their works to the public in such a way that the public may have access to these works at a place and time chosen by them individually (right of notification).

Restrictions have determined by the conditions:

- in certain special cases;

- such reproduction does not contradict the normal operation of the work;

- does not harm the legitimate interests of the author.

Such restrictions and exceptions established by national law in accordance with the Berne Convention may apply to the digital environment. The Contracting States may develop new exceptions and limitations appropriate to the digital environment.

The related rights have related to copyright, but exist in their own right. Their purpose is to protect the legal and economic interests of certain individuals and legal entities that participate in the work in various ways and promote their accessibility to the public. Thus, the overall purpose of these related rights is to protect those people or organizations that add significant creative, investment, or organizational skills to the use of the work.

At the international level, a system of related rights was created, in Rome in 1961 signed the Convention for the Protection of Performers, the Producers of Phonograms and the Broadcasting Organizations (Rome Convention). Under the Rome Convention, three main categories of right holders were considered to be deserving of protection:

- the performers (actors, dancers, etc.): because their creative intervention gives life to the works they perform;

- the producers of phonograms: in order to ensure the protection of their efforts and investments, including by taking measures against unauthorized use;

- the organizations Broadcasters: because they play a role similar to that played by phonogram producers, and they should have the right to control the transmission and retransmission of their broadcasts and to recoup their investments.

All WTO members have obliged to implement all agreements resulting from the negotiations on the General Agreement on Tariffs and Trade (GATT).

In December 1996, the Performances and Phonograms Treaty (WIPO) renewed the related rights of performers and producers of phonograms with regard to the Internet for the use and delivery of 
works based on digital technologies and the Internet.

The Beijing Agreement on Audiovisual Performances (2012) provides for the presumption of the transfer of an exclusive right to a producer, subject to the performance of the audiovisual fixation contract between the performer and the producer as defined by national law (Article 12). The Beijing Treaty also deals with related rights of performers and gives them four types of economic rights, namely:

- the right to reproduce, ie to allow direct or indirect reproduction of a performance recorded in an audiovisual recording, in any way or in any form;

- the right of distribution, ie to allow the public to provide the original and copies of the performance recorded in the audiovisual recording, by sale or other transfer of ownership;

- the right to rent, ie to allow commercial rental to the public of the original and copies of the performance recorded in the audiovisual recording;

- the right to make available, ie publicly, by wire or wireless means, to make available to the public any performances recorded in the audiovisual recording.

The Beijing Treaty, which is open to WIPO member states and the European Union, has gained a key 30th member, allowing it to enter into force for its 30 contracting parties on April 28, 2020.

The national and the international law has enacted legislation to limit the ability of users to circumvent certain DRM measures. The Copyright and Related Rights Treaties, adopted by WIPO in December 1996 (Halaburda, 2018), impose an obligation to provide adequate legal protection and remedies against the circumvention of effective TPM and deletion or modification RMI (Heap, 2017).

States fulfilling international obligations have adopted national schemes, such as the US Copyright Act in the Digital Age (Hilty, 2016; Hohmann, 2016) or the European Union Information Society Directive (InfoSoc Directive) (Hilty, 2018).

The WIPO published a concept paper on intellectual property and artificial intelligence policy issues (Revised Issues).

The copyright redemption is now an urgent problem, especially in the crisis after the COVID-19 pandemic. The problem is the lack of information and training materials on various national laws related to redemption, as well as uncertainty about the legal environment around the world. In response, new guidelines have been published (CISAC) that explain what foreclosures are, what laws apply in different markets, what negotiating positions creators should follow, and what options are available to address this issue.

The European Commission has launched a public consultation on proposals for a digital services package (DSA) aimed at modernizing the existing EU legal framework for digital services.

The existing contradictions in international law to ensure copyright law have given rise to a number of restrictions and disputes. The latest digital technologies are being updated to create smart contracts as a potential alternative to existing systems.

\section{Methodology}

The methodological basis of this article are general scientific and empirical research methods. Research methods have selected based on the object, subject and purpose of the study. The study used general and special methods of legal science. The method of analysis and synthesis has used to conduct a complete and comprehensive study of the characteristics of international legal regulation of copyright and related rights in the digital environment

Methods of analysis and synthesis were used to form a holistic view of the problem of regulating the protection of copyright and related rights in the digital environment. The logical-semantic method was used to study the current legislation governing the prevention of this type of crime, to establish the meaning of basic concepts and analysis of the main manifestations of crime in the field of copyright and related rights in the digital environment. The comparative method was used to study the deterministic complex of crime in the field of intellectual property and the system of prevention of this 
phenomenon. The priority methods and the ways of legal regulation of public relations arising from the use of the global computer network Internet are public and private law methods (method of legal equality of the parties),

The method of legal modeling has used to compare the provisions of the legislation of Ukraine with the relevant provisions of the legislation of other states and international legal acts. Based on the results of sociological research methods in the form of a questionnaire, the current state of crime prevention in the field of intellectual property was determined. The study was conducted on the basis of information USA, European Union, China - to identify the latest trends in copyright and related rights protection in the digital environment.

Empirical basis of the study are the results of a study of materials of the State Statistics Service of Ukraine, the official websites of the state budget institutions, the statistics of the Supreme Court, the Prosecutor General's Office and the Unified State Register of Court Decisions, the generalized data of the criminal proceedings on intellectual property offenses, international experts, Internet resources.

\section{Evaluation and analysis of results}

\subsection{Characteristics of legal relations in the digital environment}

The legal relations in the digital environment, which have related to the functioning of the Internet (Internet relations), address the following issues:

- the content regulation (the content - the information content of Internet resources);

- the cybercrime prevention;

- the protection of a confidential information and a personal data;

- the protection of an intellectual property rights;

- the e-commerce (the trade);

- the consumer protection;

- the protection of a human rights.

A signs of such legal relations are:

- the information has exchanged in an electronic digital form;

- the remoteness of the subjects of these relations in space;

- the presence of entities that did not initiate these relations, but had the organizational and technical ability to influence them;

- use of a software, a technical standards and a protocols;

- the tendency of these relations to self-regulation;

- the technological complexity of the Internet;

- the widespread opportunities for violation of an information rights of the subjects of these relations;

- a technical, a cultural and an educational qualifications of the subjects of these relations.

Features of legal relations in the digital environment:

- an availability of the technical component;

- use of information and telecommunication technologies and networks;

- an information content;

- a special subject composition.

Thus, legal relations in the digital environment are social relations that exist in electronic-digital form in cyberspace. The subjects of these relations may be located in different countries, their activities have governed by the laws of different countries.

The Figure 1 shows the classification of relationships in the digital environment. 


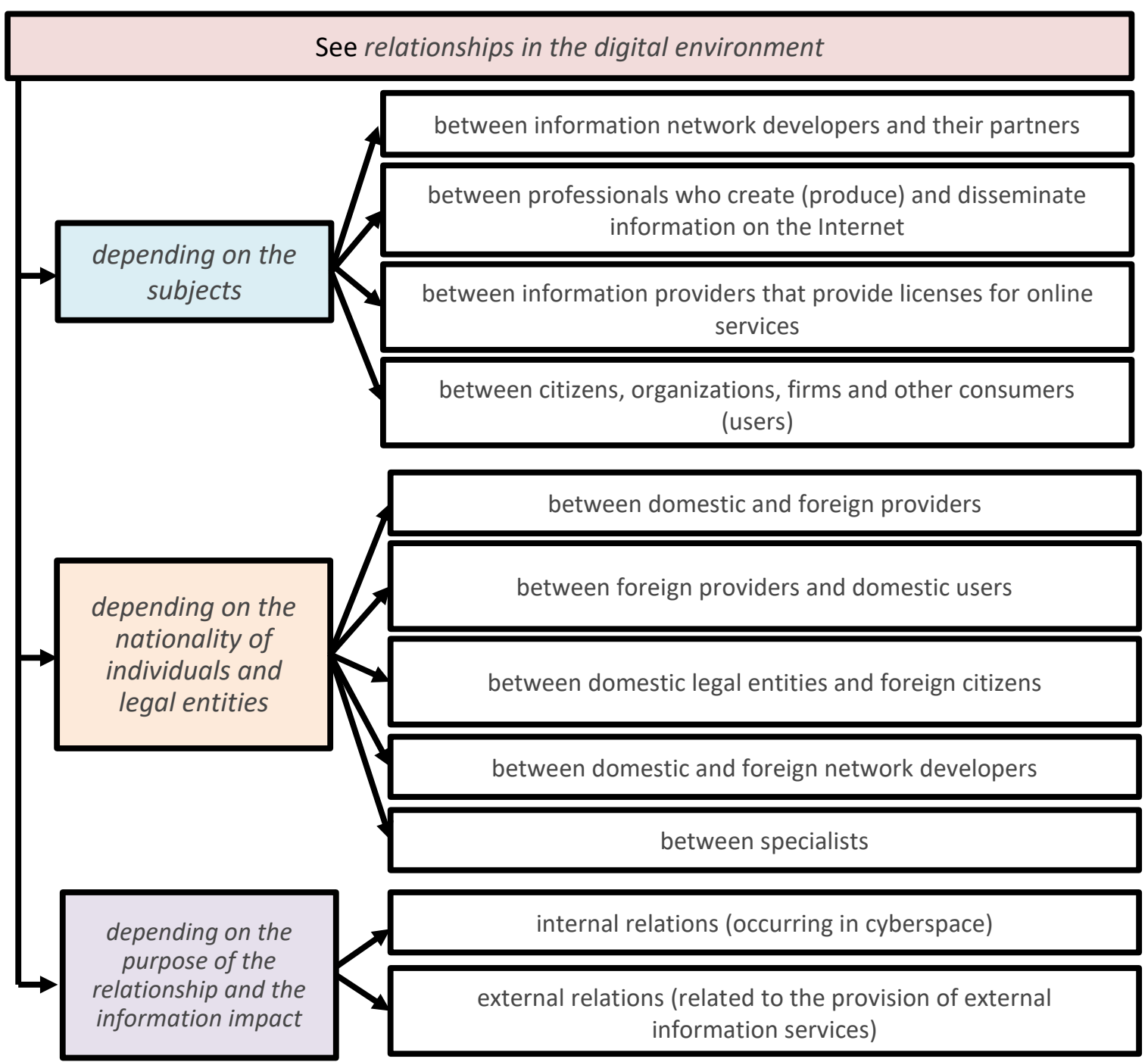

Figure 1. Classification of relationships in the digital environment

The relationships in the digital environmentcan were classified according to the following characteristics:

1) depending on the subjects: between the developers of information networks and their partners; between professionals who create (produce) and disseminate information on the Internet; between information providers that provide licenses for online services; between citizens, organizations, firms and other consumers (users);

2) depending on the nationality of individuals and legal entities: between domestic and foreign providers; between foreign providers and domestic users; between domestic legal entities and foreign citizens; between domestic and foreign network developers; between specialists;

3 ) depending on the purpose of the relationship and the information impact: internal relations (occurring in cyberspace); external relations (related to the provision of external information services).

Thus, the internet relations are public relations in cyberspace, the participants of which are the bearers of subjective rights and responsibilities on the Internet. The internet relations are special social relations that arise as a result of the influence of the norms of an information, a computer, an international and other branches of law, an international agreements on the behavior of the subjects of these relations. The internet relations are a new type of social relations that arise, change and the end in cyberspace. These are not only legal, factual, ethical relations, they are complex social connections of special legal, informational and technical nature. 
The legal regulation of relations in the digital environment should be purposeful to influence the processes by legal means in order to streamline and develop them. This concerns, first of all, the behavior of legal entities through the rules of law, which ensures their normal operation.

After all, the Internet forms a special information sphere associated with the circulation of the digital information. Legal regulation of relations in the digital environment has associated with the socio-legal regulation of virtual space, ie with the regulation of this space through the rules of law, morality, ethics and other means.

The Figure 2 presents a diagram of legal relations in the digital environment.

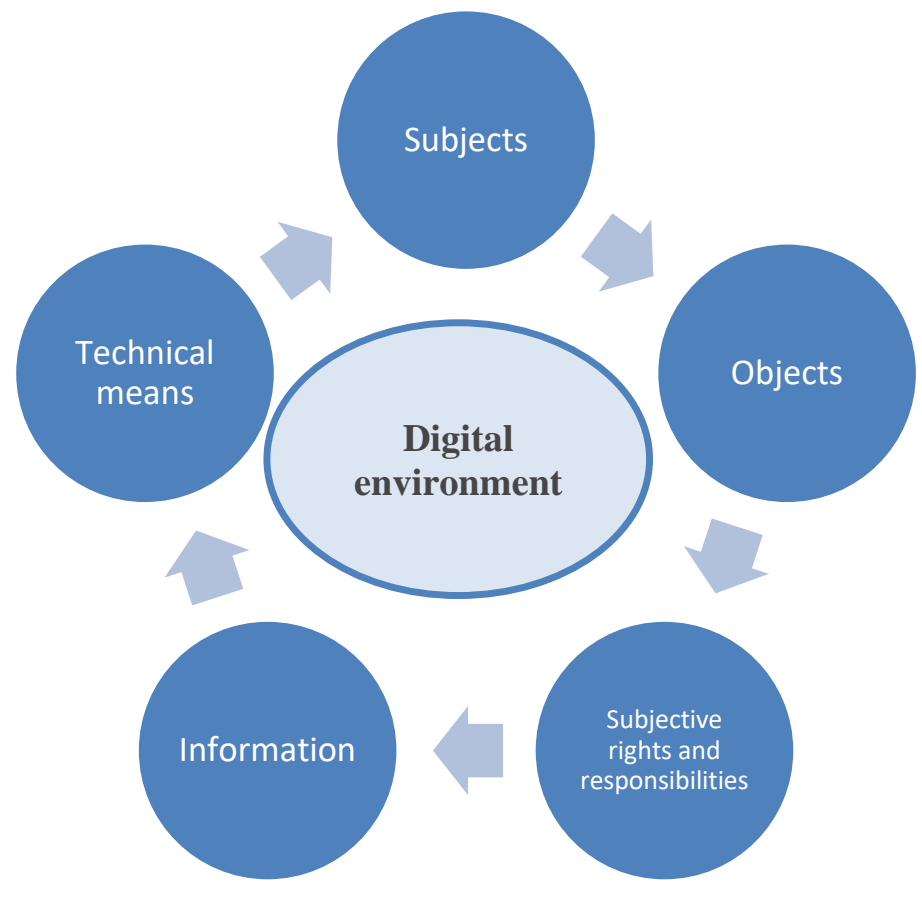

Figure 2. Scheme of legal relations in the digital environment

The structure of Internet relationscontains the following components: subjects, objects, subjective rights and responsibilities, information, technical means.

The subjects of such relations are the participants of information contacts and processes, participants of communication and information interaction. In the information space and processes there are many intermediaries - providers or operators in the Internet and other entities that provide various types of services. One of the important factors in the field of the Internet is the "virtualization" of subjects and the virtualization of relations in the system of the global information interaction of various structures.

The subjects of relations in the digital environment are:

1) Telecommunications operators and providers that ensure the functioning of the Internet as an information system. Provide the following main types of information services:

- $\quad$ connection (providing access to the network);

- $\quad$ administration (ensuring the functioning of technical means to support the Internet address space);

- hosting (placement of customer information resources on web servers and providing access to these resources);

- network navigation services (creation of web portals that facilitate the search and access to information resources of the network).

2) Manufacturers, owners and distributors of information and information resources that create the content of the Internet. These entities: 
- the create electronic information resources;

- $\quad$ have rights to them;

- $\quad$ ensure the functioning of these resources;

- meet the information needs of users.

3) Entities that provide specific services for the conclusion of the electronic (network) agreements (contracts) through the Internet, ie all that has covered by the term "e-commerce (trade)". These are: Online stores, Online casinos, Online auctions, etc.

4) Consumers (users) of telecommunication services: an individuals and a legal entities that need, order, receive telecommunication services for their own information needs.

The specificity of the digital environment is that it is not important whether the network user is a natural or legal person or whether the network service operator was registered as a taxpayer. The subjects of legal relations may be public authorities, as well as local governments. Since access to the Internet is currently anonymous, in some cases, determining the affiliation of the subject to the traditional in the real physical world seems difficult.

Placement of information on the Internet, access to this information, as well as "intra-network" exchange of information has carried out with the participation of specialized organizations - the Internet service providers (services). In this case, the "Internet" itself as a set of information resources is not under the control of any particular person, state or international organization. Each provider has the ability to control the information that has transmitted to the network or leaves the network when using its services. That is, each provider has the potential to set certain network usage standards for its customers. The state has the ability to regulate and control the activities of providers providing services in its territory, through various legal institutions.

The objects of legal relations on the Internet are:

- a telecommunication networks and other technical equipment;

- a computer software;

- $\quad$ an information, an information resources, an information products, an information services;

- a domain names;

- a rights and a freedoms in the field of information;

- an informational security.

The main object of relations that develop in the network is information (a technical, an economic, a social, a legal, etc.). Today, the information blurs the boundaries between product and service, which has embodied in the modern technologies that combine information products and services into a single whole.

Thus, the legal norms governing the Internet were of a mixed private-public nature. Also, the legal relationships on the Internet have often understood as public relations formed on the basis of the use of the Internet and other information and communication technologies (for example, software) between the Internet service providers, the information providers and users, which have formed on the basis of mutual recognition given by the subjects of freedom and formal equality.

Thus, the legal relations in the digital environment are a legal form of interaction of the Internet users on the exchange of various information, have a voluntary nature and together consist of a set of absolute and relative, regulatory and protective legal relations. The peculiarity of these legal relations is that the subjective rights in them, first of all, have revealed through the own actions of the Internet users, which cause the emergence, termination or change of rights and responsibilities of other Internet participants, and not only through responsibilities third parties (the information providers and owners of the Internet sites). 


\subsection{Investigation of crime in the field of intellectual property}

An intellectual property crime has committed when someone uses intellectual property rights without the owner's permission. It is the illicit production, sale or distribution of counterfeit or pirated goods, such as patents, trademarks, industrial designs or literary and artistic works, for commercial gain (Hetzer, 2002). A counterfeiting and a piracy were terms used to describe a number of illegal acts involving infringements of intellectual property rights. In the most cases, a counterfeiting infringes a trademark, which means that the product has produced without the permission of its rights holder.

The piracy refers to the illegal use of unlicensed software, online books, video games, movies, music with respect to the rights of copyright holders, literary and artistic works protected by copyright. The EUIPO estimates that the annual damage caused by counterfeiting and piracy in some sectors of the EU economy is up to 60 billion $€$ (Table 1).

Table 1. Estimated direct and indirect infringement economic costs - selected IPR intensive industries in the EU (average annual figures, 2012-2016)

\begin{tabular}{|l|c|c|c|c|c|c|}
\hline \multicolumn{1}{|c|}{ Sector } & $\begin{array}{c}\text { Direct Lost } \\
\text { Sales } \\
\text { (€ billion) }\end{array}$ & $\begin{array}{c}\% \text { of } \\
\text { Sales }\end{array}$ & $\begin{array}{c}\text { Total Lost } \\
\text { sales } \\
\text { (€ billion) }\end{array}$ & $\begin{array}{c}\text { Direct } \\
\text { Employment } \\
\text { Loss }\end{array}$ & $\begin{array}{c}\text { Total } \\
\text { Employment } \\
\text { Loss }\end{array}$ & $\begin{array}{c}\text { Government } \\
\text { Revenue } \\
\text { Loss }\end{array}$ \\
\hline Smartphones * & 4.2 & $8.3 \%$ & $\begin{array}{c}\text { Not } \\
\text { calculated }\end{array}$ & $\begin{array}{c}\text { Not } \\
\text { calculated }\end{array}$ & calculated & calculated \\
\hline $\begin{array}{l}\text { Pesticides \& } \\
\text { Agrochemicals }\end{array}$ & 1.0 & $9.8 \%$ & 2.1 & 1,749 & 7,993 & 0.3 \\
\hline Pharmaceuticals & 9.6 & $3.9 \%$ & 16.5 & 33,133 & 80,459 & 1.7 \\
\hline Spirits \& Wine & 2.4 & $5.9 \%$ & 6.1 & 6,049 & 38,885 & 2.1 \\
\hline Recorded Music & 0.1 & $3.6 \%$ & 0.2 & 580 & 1.343 & 0.1 \\
\hline $\begin{array}{l}\text { Jewellery \& } \\
\text { Watches }\end{array}$ & 0.9 & $6.2 \%$ & 1.7 & 5,683 & 11,882 & 0.3 \\
\hline $\begin{array}{l}\text { Handbags \& } \\
\text { Luggage }\end{array}$ & 1.0 & $7.4 \%$ & 2.1 & 8,169 & 16,550 & 0.4 \\
\hline Toys \& Games & 1.0 & $7.4 \%$ & 1.6 & 3,679 & 8,158 & 0.3 \\
\hline Sports Goods & 0.3 & $4.1 \%$ & 0.6 & 1,756 & 3,625 & 0.1 \\
\hline $\begin{array}{l}\text { Clothing, } \\
\text { Footwear } \\
\text { and Accessories }\end{array}$ & 28.4 & $9.7 \%$ & 45.9 & 335,053 & 473,031 & 8.6 \\
\hline $\begin{array}{l}\text { Cosmetics \& } \\
\text { Personal care }\end{array}$ & 7.1 & $10.5 \%$ & 11.2 & 71,984 & 118,654 & 2.6 \\
\hline \begin{tabular}{l} 
Total all sectors \\
\hline
\end{tabular} & 56.0 & $\begin{array}{l}7.4 \% \\
(a v g .)\end{array}$ & 92.3 & 467,835 & 760,579 & 16.3 \\
\hline
\end{tabular}

${ }^{*}$ Figures for this sector refer to 2015 only.

Source: 2019 Status Report on IPR infringement

The intellectual property crime has a significant negative impact on the economy. The updated analysis shows that the total losses are equivalent to $7.4 \%$ of total sales in the $E U$ in the 11 surveyed sectors of the economy, within the EU up to 468,000 jobs are lost in these areas.

Most counterfeit goods have manufactured without EU quality and safety standards. Such products are dangerous for consumers. Therefore, the task of law enforcement agencies is the timely detection of such crimes and their prevention. Organized crime groups were increasingly involved in infringing intellectual property rights. In addition, criminal groups involved in intellectual property crime often use profits to fund other illegal activities. That is, in addition to the direct economic consequences, infringements in the field of intellectual property can also have dynamic, long-term consequences.

The fight against intellectual property crime has been identified as a key priority for Europol and its partner law enforcement agencies.

The cross-border organized crime is a natural habitat and a way of committing crimes in the field of intellectual property. To strengthen the fight against counterfeiting and piracy, in 2016 Europol and the European Union Intellectual Property Office (EUIPO) joined forces to form a Coordinating Coalition 
on Intellectual Property (IPC3). The EUIPO is an EU decentralized agency based in Alicante, Spain. It manages the registration of EU trade marks (EUTM) and Community industrial designs (RCDs), which ensure the protection of intellectual property in all EU Member States. The EUIPO also cooperates with EU national and regional intellectual property offices. The European Observatory on Intellectual Property Infringement was established in 2009 to support the protection and enforcement of intellectual property rights and to help combat the growing threat of intellectual property infringement in Europe.

The European Union Intellectual Property Office (EUIPO) and the European Union Agency for Criminal Justice Cooperation (Eurojust) are stepping up their cooperation to combat criminal misuse of intellectual property rights in the field of counterfeiting and piracy on the Internet. The Eurojust is the European Union Agency for Criminal Justice Cooperation. Based in The Hague, the Netherlands, it promotes cross-border judicial cooperation for all $27 \mathrm{EU}$ Member States and 13 countries with which it has cooperation agreements covering all areas of major crimes.

The Agreement service level (SLA) provides additional funding to Eurojust by the end of 2024 for $€$ 750,000 , which will help build additional expertise to combat crime in the field of copyright and related rights in the digital environment.

The intensification of cooperation between the EUIPO and the Eurojust will contribute to the establishment of the European Network of Intellectual Property Prosecutors (EIPPN).

In recent years, Eurojust has given priority to combating large-scale copyright infringements; for example, by organizing major operations against audiovisual piracy. Since September 2019, six major days of action have been organized in cooperation with Member States such as Italy, Spain, the Netherlands, Germany and France and third countries such as Canada, Switzerland and the United States. Such actions have led to the dismantling of criminal networks that illegally offered online broadcasting and video-on-demand services to viewers around the world without paying copyright to legitimate TV channels and film studios. As a result, nearly 6,000 computer servers used to transmit illegal signals were seized.

\subsection{Protection of intellectual property rights in Ukraine}

In 2019, the Office of the United States Trade Representative (USTR) published Special Report 301 on the adequacy and effectiveness of protecting the intellectual property rights of US trading partners around the world. According to this report, Ukraine remained on the Priority Watch List in 2019 (which has been mentioned since 1997). Among the problems that led to Ukraine's participation in this list, in particular, the lack of effective means to combat widespread copyright infringements in Ukraine using the Internet. With regard to software legalization, according to the latest global review of the Business Software Association (BSA), published in 2016, the approximate use of unlicensed software in Ukraine was $82 \%$, estimated at $\$ 129$ million.

Regarding the criminal law protection of intellectual property rights, the overall crime rate in this area remains high.

The reasons for this condition are:

- $\quad$ the presence of problems and inconsistencies of legal norms;

- $\quad$ the absence of certain law enforcement agencies, which are under investigation for specific types of crimes in the field of intellectual property;

- low motivation of law enforcement officers to conduct quality investigations of crimes in this area, insufficient level of their qualifications;

- low level of legal culture of the population and public awareness of intellectual property rights, which often causes unconscious violation.

Currently, the Ukrainian legal field has not formed a systematization of criminal law relating to the protection of intellectual property rights. The objective side of crimes in this area was not specified. There are imperfections in the legislative technique in the presentation of the relevant articles of the 
Criminal Code on criminal law protection of intellectual property rights. There are differences in the terminology of the Criminal and Civil Codes of Ukraine, as well as special laws in the field of intellectual property for specific objects.

Analysis of the criminogenic situation in the consumer market of Ukraine showed that illegal activities often take the following forms:

1) the production of various types of the counterfeit products with illegal use of trademarks and brand names of well-known domestic and foreign manufacturers;

2 ) the violation of rights to industrial property;

3 ) the illegal distribution of objects of copyright and related rights on the Internet;

4) the copyright infringement in the computer software market;

5 ) the illegal public notice (bringing to the public knowledge of copyright and related rights).

The Figure 3 provides information on the registration of applications and notifications of intellectual property offenses in Ukraine.

Figure 3. Dynamics of registration of applications and notifications of criminal offenses in the field of intellectual property in Ukraine in 2015-2019

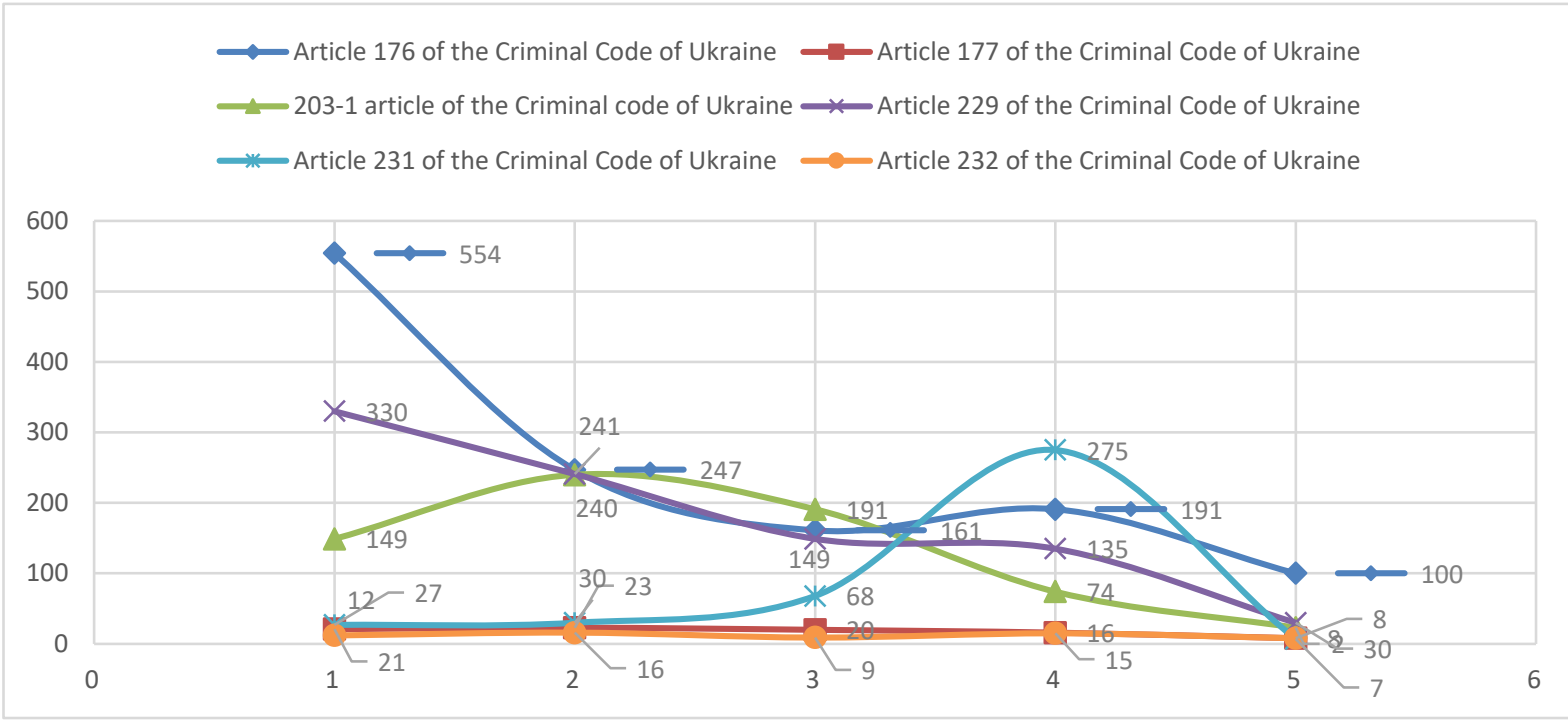

According to statistics, over the past 5 years, the Unified Register of the Pre-trial Investigations has included information on the commission of 6,915 criminal offenses in the field of intellectual property and have send to the court materials on the commission of 880 such offenses, of which under Art. 176 of the Criminal Code of Ukraine - 445, under Art. 177 of the Criminal Code of Ukraine - 8, according to Art. 229 of the Criminal Code of Ukraine - 175, according to Art. 231 of the Criminal Code of Ukraine 201. Thus, only every eighth appeal to the law enforcement had a judicial perspective. That is, despite the relatively large share of the infringements of intellectual property rights, only a small proportion of registered criminal proceedings bring the case to court, which negatively affects the overall criminogenic situation regarding the protection of intellectual property rights. Example, in the first quarter of 2020, the Appeals Chamber received 21 objections against the decisions of the Ministry of Economy, which were distributed by industrial property as follows: the signs for goods and services 19; the inventions - 1, the utility models - 1.49 meetings of the Boards of Appeal were held.

The appellants were sent 27 decisions of the Appeals Chamber, of which 12 decisions on satisfaction of the objection in full and 15 - on the refusal to satisfy the objection. In the first quarter of 2020, 86 procedural documents (reviews, objections, explanations, petitions, complaints) were prepared. 33 claims and 37 decisions of courts of first, appellate and cassation instances were processed. Participated in 269 court hearings.

In order to implement court decisions (rulings on securing claims), measures were taken to: secure claims - 24, cancel the provision of claims - 14, execution of court decisions - 21.204 documents related 
to the execution of court decisions were prepared. Data on appeals against decisions of the Ministry of Economy to the Appeals Chamber and the court, as well as on lawsuits for invalidation of security documents in the first quarter of $\mathbf{2 0 2 0}$ are given in the Table 2.

Table 2. Appeals against decisions, lawsuits for invalidation of security documents in the first quarter of 2020 (Ukraine)

\begin{tabular}{|c|c|c|c|c|c|}
\hline Legal affairs & Inventions & $\begin{array}{l}\text { Useful } \\
\text { models }\end{array}$ & $\begin{array}{l}\text { Signs for } \\
\text { goods and } \\
\text { services }\end{array}$ & $\begin{array}{l}\text { Industrial } \\
\text { designs }\end{array}$ & Total \\
\hline Decisions have been made & 594 & 1878 & $8452 *$ & 557 & 11481 \\
\hline \multirow{2}{*}{$\begin{array}{l}\text { Objections filed with the } \\
\text { Court of Appeal } / \%\end{array}$} & 1 & 1 & 19 & - & 21 \\
\hline & $0.2 \%$ & $0.01 \%$ & $0.2 \%$ & - & $0.2 \%$ \\
\hline \multirow{2}{*}{$\begin{array}{l}\text { Lawsuits filed against } \\
\text { decisions } / \%\end{array}$} & 1 & - & 1 & - & 2 \\
\hline & $0.2 \%$ & - & $0.01 \%$ & - & $0.01 \%$ \\
\hline Decisions declared invalid & - & - & - & - & - \\
\hline Security documents issued & 510 & 1942 & $6830 * *$ & 388 & 9670 \\
\hline \multirow{2}{*}{$\begin{array}{l}\text { Claims for invalidation of } \\
\text { security documents } / \%\end{array}$} & 1 & 1 & 10 & 3 & 15 \\
\hline & $0.2 \%$ & $0.05 \%$ & $0.1 \%$ & $0.8 \%$ & $0.1 \%$ \\
\hline \multirow{2}{*}{$\begin{array}{l}\text { The courts declared the } \\
\text { security documents invalid }\end{array}$} & - & 1 & 16 & 1 & 18 \\
\hline & - & $0.1 \%$ & $0.2 \%$ & $0.3 \%$ & $0.2 \%$ \\
\hline
\end{tabular}

*Including according to international applications under the Madrid Agreement - 2499

**Including international registrations under the Madrid Agreement - 2416

According to the Report of the Appeals Chamber, out of 100 decisions adopted by the Chamber from 01.06.2017 to 01.09.2018, only 5 were appealed to the court. The proceedings in these cases are ongoing (the Report of the Appeals Chamber). In 2018, representatives of Ukrainian patent took part in more than 500 cases related to security documents. In these cases, 516 procedural documents were prepared, 1,664 court hearings were attended, and 261 court decisions were processed. In 2018, 203 cases were initiated, 145 of them concerned marks for goods and services, 20 - inventions, 21 industrial designs, 17 - utility models. By jurisdiction, these cases were distributed as follows: 92 cases were considered in commercial courts; in civil courts - 78; in administrative courts - 33. Of the 145 cases concerning trademarks for goods and services, 43 concerned the early termination of security documents. 102 other claims concerned, in particular, the invalidation of security documents. In order to implement the decisions (rulings) of the courts, measures were taken to secure 91 claims, cancel the measures to secure 28 lawsuits, and executed 75 court decisions. 568 documents were sent regarding the execution of court decisions. In 2018, according to court decisions, 40 certificates for marks for goods and services, 11 patents for industrial designs, 8 patents for utility models and 1 patent for an invention were declared invalid. 568 documents were sent regarding the execution of court decisions.

A similar picture is inherent in the consideration of proceedings under other articles. A number of crimes against intellectual property (Part 1 of Articles 176 and 177, Article 203 Of the Criminal Code of Ukraine) referred to cases of private prosecution, ie these cases have initiated by the victim (right holder). Sometimes there is a delay in obtaining the status of a victim, which has its continuation in the form of disinterest of the law enforcement agencies to conduct a quality investigation of the fact.

The situation with the criminal-legal protection of intellectual property was negatively affected by the problems of overloading judges with cases, which is evidence of the irrationality of the organization 
in the judiciary. In addition, there is the problem of determining the amount of material damage caused by the crime. In the provided art. 176, 177, 229 Of the Criminal Code of Ukraine acts, the criminal consequences in the form of the material damage is a qualifying feature, but today the regulations do not have a clear position on how to establish the size of these criminal consequences.

At the same time, sanctions for committing crimes against intellectual property in Ukraine were quite mild compared to developed countries. There is no single approach in determining sanctions for infringements of intellectual property rights in Articles 176, 177, 229 Of the Criminal Code of Ukraine. The amount of fines in all articles is significantly understated and does not correspond to the amount of material damage, which is mandatory for the qualification of the relevant actions as crimes. The sanctions of these articles do not include such an effective additional punishment as confiscation and destruction of all counterfeit products and tools and materials used for its manufacture.

Ukraine still has a significant number of problems in the protection of intellectual property rights, which requires the involvement of law enforcement agencies.

Despite positive legislative changes, the Internet piracy in Ukraine continues to spread. As of 2016, Ukraine was among the top five countries in terms of the number of peer connections for illegal file sharing of video games. In 2017 and 2018, Ukraine ranked third in the world in the number of infringements of intellectual property rights to video games for personal computers (IIPA 2019).

No less a problem is e-commerce with counterfeit goods through the relevant trading platforms (online stores and marketplaces). However, these forms of infringement of intellectual property rights to trademarks and commercial (brand) names remained outside the boundaries of law enforcement agencies. The fact that the investigation of crimes against intellectual property rights belongs to the jurisdiction of the police, which also investigate numerous general criminal offenses, is not conducive to bringing perpetrators to justice.

In addition, in accordance with paragraph 1 of Part 1 of Art. 477 of the Criminal Procedure Code of Ukraine, the criminal proceedings for all these criminal offenses belong to the criminal proceedings in the form of private prosecution and can be initiated by the investigator, prosecutor only on the basis of the victim's application for the criminal offenses. Thus, in a crisis in the Ukrainian law enforcement system, in fact, the burden of proving the composition of a criminal offense rests with the right holder. This applies in particular to proving the fact of infliction of damage, the minimum necessary for the qualification of a criminal offense. At the same time, the rightholders and the collective management organizations have often deprived of the ability to record and secure evidence. Therefore, one of the main criteria for improving the effectiveness of criminal law protection- is intellectual property.

\subsection{International initiatives}

For the EAEU countries, the development of the intellectual property is a topical issue (EAEU). The main task of the Advisory Committee on Intellectual Property at the Board of the United Nations Economic Commission for Europe (UNECE) is to develop proposals on the protection and enforcement of intellectual property rights in the Eurasian Economic Union (EAEU). Recent initiatives have been:

- proposals of the Republic of Belarus on the study of mutual experience in the matters of state incentives for the creation and use of intellectual property, the development of harmonized approaches to determining the amount of damages from the violation of the exclusive right to intellectual property;

- the proposal of the Russian Federation to create a Unified Register of the Pharmacological Activity of Protected Substances (the patents for inventions) on the territory of the EAEU Member States (the Unified Register) and the participation of patent offices in the creation and maintenance of the Unified Register.

The European Commission has implemented Directive 2019/790 / EU on copyright in the digital single market, which complements Directives 96/9 / EC and 2001/29 / EC (Directive (EU) 2019). Conceptually new are the provisions of the Fair Remuneration Directive for authors and performers. A mechanism for reviewing concluded agreements on transfer of rights and license agreements has also 
been developed. In addition, a new model of the relationship between creators and the media, the publishing business has been developed.

The European Commission has launched a public consultation on proposals for a Digital Services Package (DSA).

The EU legal framework for digital services has remained unchanged since the adoption of Directive 2000/31 on electronic commerce, which harmonized the basic principles governing the cross-border provision of services. However, Europe needs a modernized regulatory framework to reduce the everincreasing fragmentation of regulation between the Member States, as well as to ensure that every EU citizen has protected both online and offline, and to offer all European companies a level playing field for innovation, growth and competition in all over the world (Public consultation).

Thus, the DSA package will consist of two main components:

- a new rules defining the responsibility of digital services for eliminating the risks faced by their users and protecting their rights;

- an increase and harmonize the responsibility of online platforms and information service providers;

- a strengthening oversight of platform content policy in the European Union;

- a rules that provide all players with fair and competitive conditions in markets characterized by large platforms with significant network effects acting as intermediaries.

Thus, the following issues that need to be addressed are relevant:

- how to effectively ensure the safety of users on the Internet by collecting experience and data on illegal activities on the Internet;

- what responsibilities should be legally binding from online platforms and under what conditions;

- what issues arise from the power of intermediaries - digital platforms;

- the issue of regulating the activities of large companies - platforms that act as intermediaries;

- issues related to online advertising, including political advertising on the Internet;

- the position of self-employed persons providing services through platforms;

- a digital services management and various aspects of law enforcement.

China seeks to strengthen copyright protection for photographic works and to promote a long-term mechanism for copyright protection for such works (China strengthens photo). Considerable attention is paid to the legal protection of copyright for news events - thematic photographs. Work is also under way to regulate the misconduct of stock photography suppliers, including counterfeit copyrights and permission errors, and to improve copyright protection for photographic works.

The Chinese government has launched a nation wide campaign to combat online copyright infringement and piracy, at the initiative of the National Copyright Office in cooperation with several other ministries.

During the campaign, law enforcement will combat copyright infringement on audiovisual works, including films, short videos, and content that is transmitted through streaming media (China launches).

E-commerce platforms will also be closely monitored during the special operation. It has noted that, in particular, strict measures will be taken to limit online sales of pirated books, audiovisual products and electronic publications. Regulators will focus on combating copyright infringement on social networking platforms, as well as online education and training. The Crackdown is the 16th national campaign to prevent online copyright infringement since 2005.

Amendments to China's copyright law impose penalties for the first time, give the government greater powers to investigate violations, and record the rapid development of the digital technology (China's Copyright Law). 
The Copyright Act was passed in 1991 and amended in 2001 and 2010. In April 2020, Chinese lawmakers began considering the Third Amendment.

The most significant change concerns compensation for damages (Article 53).

The statutory damage to the project was increased tenfold from 500,000 to 5 million yuan (from 70,000 to 700,000 US dollars). The project introduces a new system for calculating compensation for penalty damages, which has based either on the actual damage suffered by the right holder, or on the illegal profits of the infringer, or on a multiple of standard royalties. This helps rightholders to receive fair compensation, significantly increasing the cost of the violation.

In order to facilitate the detection of illegal income of the violator, the draft proposes to give administrative bodies the right to the investigate interested parties, the investigate illegal actions, the conduct on-site inspections, consult and copy the relevant materials, and seal and detain the sites and goods during investigations (Article 54).

The draft law changes the term "cinematographic works and works created as a result of an analogous process in the cinematography" to the "audio-visual works" (Article 3.6, Article 10.1.7, Article 15, Article 21.3, Article 46 and Article 48.8) and clarifies the definition of "the right to broadcast" from "the right to broadcast or transmit a work by wireless means" to the "Right to broadcast or transmit a work by wire or wireless means" (Article 10.1.11).

These amendments have designed to bring the law in line with modern technological realities and to protect the content of the new format, regardless of the technology used. The draft law also expands the provisions on technological protection measures and helps to avoid any possibility to circumvent it (Articles 47-50).

The scope of copyright protection itself is expanding: now works that were not protected by copyright do not include "news of current events", but only "pure factual information" (Article 5.2). The amendment stipulates that commentary texts, photographs, audiovisual works and other news content have protected by copyright if they meet the requirement of originality.

The draft law extends the term of protection granted to "photographic works" from fifty years from the date of publication to the period of the author's lifetime and fifty years after his death (Article 21.3).

In order to comply with international treaties, the draft revises the provisions on authorship by changing the original description of "citizens" to "individuals" and "other organizations" to "unincorporated organizations" (Articles 2, 9, 11, 16, 19, 21 and 22).

Thus, the introduction of such amendments will strengthen copyright protection, especially in the digital environment. At the same time, the bill strengthens supervision and punishment for violations, which in the future will serve as an even greater deterrent. Increasing the amount of damage provided by law and the inclusion of penalties will encourage the parties to defend their intellectual property rights.

The international experience shows that alternative dispute resolution, such as arbitration and mediation, has a number of advantages over litigation: discretion, confidentiality and speed of dispute resolution. Resolving the issue of jurisdiction of a dispute in the field of intellectual property in each case requires an analysis of the circumstances of a particular case. Some categories of disputes, such as disputes over the invalidation of protection documents on intellectual property rights, are not subject to arbitration and international commercial arbitration.

A necessary precondition for applying to an arbitral tribunal or international commercial arbitration is the existence of an agreement between the parties (arbitration or arbitration clause or a separate agreement on the transfer of the dispute to the relevant authority). According to the Main Department of Statistics in Kyiv, as of June 11, 2019, no specialized arbitration court or international commercial arbitration in the field of intellectual property has been registered in the Unified State Register of Enterprises and Organizations of Ukraine in Kyiv.

A necessary condition for the effective protection of intellectual property rights is the creation of a 
single platform of all bodies involved in the protection of intellectual property rights, which will operate behind closed doors.

\section{Conclusion}

In this study the main aspects of international legal regulation of copyright and related rights protection in the digital environment are considered

It has established that the digital environment forms the newest type of legal relations, which requires modification of copyright legislation. International experience on the latest trends in copyright and related rights protection in the digital environment was discussed. It has established that the key trend of modificationinternational legal regulation of copyright and related rights in the digital environment there are stricter measures to restrict online sales of pirated books, audiovisual products and electronic publications. Particular attention has paid to combating copyright infringement on social networking platforms, as well as in the field of online education, training, ecommerce.

The analysis was performedcrimein the field of intellectual property of Ukraine. The analysis shows that in Ukraine there is currently no specialized court for resolving disputes in the field of intellectual property. An important element in improving the special criminological mechanism for preventing intellectual property crime is the IP specialization of a judge, which becomes the main prerequisite for obtaining a quality, properly motivated court decision. International experience shows that alternative dispute resolution, such as arbitration and mediation, has a number of advantages over litigation: dispositiveness, confidentiality and speed of dispute resolution. To improve the mechanism of combating crime in the field of intellectual property, it is necessary to modernize the national system of intellectual property: improving the regulatory framework, improving the institutional framework and infrastructure, as well as conducting comprehensive educational work with users of this system.

\section{References}

1. 2019 Status Report on IPR infringement: the importance of intellectual property rights, the infringement of intellectual property rights and the actions taken to combat it. URL: https://euipo.europa.eu/tunnel-

web/secure/webdav/guest/document_library/observatory/docs/2019_Status_Report_on_IPR_inf ringement/2019_Status_Report_on_IPR_infringement_en.pdf

2. Article 6 bis of the Berne Convention for the Protection of Literary and Artistic Works (as amended on September 28, 1979), URL: https://wipolex.wipo.int/en/treaties/textdetails/12214

3. Babenko, V. (2020). Enterprise Innovation Management in Industry 4.0: Modeling Aspects. Emerging Extended Reality Technologies for Industry 4.0: Early Experiences with Conception, Design, Implementation, Evaluation and Deployment Collective monograph. Ed. by Jolanda G. Tromp et al. A John Wiley \& Sons, Inc., Publication, pp. 1-24.

4. Bakulina, O., Lehan, I., \& Bakhov, I. (2019). Cluster associations as a factor of innovative and integrative development of the economy. International Journal of Innovative Technology and Exploring Engineering, 8(10), 2249-2255. doi:10.35940/ijitee.J1122.0881019.

5. Berne Convention for the Protection of Literary and Artistic Works, URL: https://www.wipo.int/treaties/en/ip/berne/index.html.

6. Bogna, J. (2018.) Sony develops blockchain system for digital rights management. URL: https://cryptoslate.com/sony-develops-blockchain-system-for-digital-rights-management/.

7. Bondarenko, S., Halachenko, O., Shmorgun, L., Volokhova, I., Khomutenko, A. \& Krainov, V. (2021). The Effectiveness of Network Systems in Providing Project Maturity of Public Management. TEM Journal, 10(1), 358-367.

8. Bondarenko, S., Tkach, I., Drobotov, S., Mysyk, A., Plutytska, K. (2021). National Resilience as a Determinant of National Security of Ukraine. Journal of Optimization in Industrial Engineering, 14(1), 111-117 
9. China launches crackdown on online copyright infringement. URL: http://www.xinhuanet.com/english/2020-06/17/c_139146733.htm

10.China strengthens photo copyright protection. URL: http://www.xinhuanet.com/english/202006/12/c_139132360.htm

11.Cohen, J.L. (1998). Lochner in cyberspace: the new economic orthodoxy of "rights management". Mich L Rev 97, 462

12.Cortese, A. (2016). Blockchain technology ushers in "the internet of value". URL: https://newsroom.cisco.com/feature-content?articleld=1741667

13.Coyle, K. (2004). Rights expression languages: a report for the Library of Congress. URL: http://www.loc.gov/standards/relreport.pdf

14.Directive (EU) 2019/790 of the European Parliament and of the Council of 17 April 2019 on copyright and related rights in the Digital Single Market and amending Directives 96/9/EC and 2001/29/EC. (Text with EEA relevance.). OJ L 130. 17.5.2019. P. 92-125.

15.EAEU countries discussed the development of the field of intellectual property. URL: https://www.eapo.org/ru/index.php?newspress=view\&d=1040

16.Europol (2020). Intellectual property crime. https://www.europol.europa.eu/crime-areas-andtrends/crime-areas/intellectual-property-crime

17.Explaining copyright buyouts: CISAC publishes new guidelines for authors societies worldwide. URL: https://www.cisac.org/Newsroom/articles/explaining-copyright-buyouts-cisac-publishes-newguidelines-authors-societies

18. Halaburda, H. (2018). Blockchain revolution without the blockchain. URL: https://www.bankofcanada.ca/wp-content/uploads/2018/03/san2018-5.pdf.

19. Heap, I. (2017). Blockchain could help musicians make money again. Harvard Business Review. URL: https://hbr.org/2017/06/blockchain-could-help-musicians-make-money-again

20. Hetzer, W. (2002). "Godfathers and Pirates: Counterfeiting and Organized Crime. European Journal of Crime Criminal Law and Criminal Justice 10(4): 303-320.

21.Hilty, R.M. (2016). Exhaustion in the digital age. In: Calboli I, Lee E (eds) Research handbook on intellectual property exhaustion and parallel imports. Edward Elgar Publ, Cheltenham

22.Hilty, R.M. (2018) IP and private ordering. In: Pila J, Dreyfuss R (eds) The Oxford handbook of intellectual property law. Oxford University Press, Oxford, 10-47.

23. Hohmann A. (2016) Rights expression languages in libraries. URL: https://hb.divaportal.org/smash/get/diva2:970467/FULLTEXT01.pdf

24.Holovatyi, M. (2014). Multiculturalism as a means of nations and countries interethnic unity achieving. Economic Annals-XXI, 11-12, 15-18.

25.IIPA 2019 special 301 report on copyright protection and enforcement. URL: https://iipa.org/files/uploads/2019/02/2019SPEC301REPORT.pdf

26. Industrial property in figures. Performance indicators in the field of industrial property for the 1st quarter of 2020. Kyiv. 2020. URL: https://ukrpatent.org/atachs/promvlasnist-1kv-2020.pdf

27.Kuznetsov, A., Smirnov, O., Gorbacheva, L., Babenko, V. (2020). Hiding data in images using a pseudo-random sequence. CEUR Workshop Proceedings, 2608, 646-660.

28. Moser, P. (2005). How do patent laws influence innovation? Evidence from Nineteenth century World's fairs. American Economic Review, 95(4), 1214-1236

29.Podgorna, I., Babenko, V., Honcharenko, N., Sáez-Fernández, F. J., Fernández, J. A. S., \& Yakubovskiy, S. (2020). Modelling and Analysis of Socio-Economic Development of the European Union Countries through DP2 Method. WSEAS Transactions on Business and Economics, 17(44), 454-466.

30.Public consultation on digital services act package. URL: http://merlin.obs.coe.int/article/8935

31.Report of the Appeals Chamber. URL: https://www.me.gov.ua/News/Detail?lang=ukUA\&id=52bd0fd7-b62b-4917-8c58-

576d5bab9f9b\&title=ZvitApeliatsiinoiPalatiPriMinisterstviEkonomichnogoRozvitkulTorgivliUkraini

32.Revised Issues Paper on Intellectual Property Policy and Artificial Intelligence. URL: https://www.wipo.int/meetings/en/doc_details.jsp?doc_id=499504 
33.Romanenko, Y. O., \& Chaplay, I. V. (2016). Marketing communication system within public administration mechanisms. Actual Problems of Economics, 178(4), 69-78.

34.Schneider, P. (2005). International trade, economic growth and intellectual property rights: A panel data study of developed and developing countries. Journal of Development Economics, 78, 529547.

35.Special 301 submission. URL:

https://www.bsa.org/sites/default/files/2019-03/BSA2018Special301.pdf

36.The Beijing Treaty on Audiovisual Performances (2012), URL:

https://www.wipo.int/treaties/en/ip/beijing/.

37. The Rome Convention for the Protection of Performers, Producers of Phonograms and Broadcasting Organizations, URL: https://www.wipo.int/treaties/en/ip/rome/index.html.

38.The TRIPS Agreement, URL: https://www.wto.org/english/docs_e/legal_e/27-trips_03_e.htm.

39.The WIPO Copyright Treaty, URL: https://www.wipo.int/treaties/en/ip/wct/.

40.Understanding Copyright and Related Rights, WIPO. (2016). URL: https://www.wipo.int/aboutip/en/iprm/

41.Upcoming amendments to China's Copyright Law. URL:

https://www.lexology.com/library/detail.aspx?g=06106904-f091-4dea-9a80-91e457af7c26

42.WIPO Intellectual Property Handbook: Policy, Law and Use, Chapter 1, WIPO. (2004). URL: https://www.wipo.int/about-ip/en/iprm/

43.WIPO Performance and Phonograms Treaty, URL: https://www.wipo.int/treaties/en/ip/wppt/.

44.Bila, O., Gontareva, I., Babenko, V., Kovalenko, O., Gliebova, N. (2019). Organizational and Methodological Guidelines for Training Education Managers to Implement the Strategy of Corporate Social Responsibility. EECS, pp. 140-146. doi: 10.1109/EECS49779.2019.00037. 